\title{
Aproximación a la habitabilidad urbana desde la movilidad cotidiana y la proximidad. Región urbana costera Puerto Vallarta- Bahía de Banderas, México
}

Adriana Inés Olivares González ${ }^{1}$ | Carme Miralles Guash ${ }^{2}$ | Marco Francesco De Paolini ${ }^{3}$

Recibido: 10-09-2021 | Versión final: 23-10-2021

Resumen

\begin{abstract}
El objetivo de esta aportación es identificar la estructura y la habitabilidad de la Región Urbana Turística Puerto Vallarta-Bahía de Banderas a través de la movilidad cotidiana y las dinámicas de proximidad, estas últimas consideradas como un indicador de habitabilidad urbana; que es donde se centra la aportación. Los datos de la movilidad cotidiana provienen de la encuesta levantada en 2011 para la investigación "Regiones Urbanas Turísticas” (CONACYT CB-103363) y de la Encuesta Intercensal 2015, mientras que los datos demográficos y territoriales emanan del Conteo de Población y Vivienda 2005, del Censo General de Población y Vivienda 2010 y de la información vectorial del Marco Geoestadístico versión 5.0 del INEGI. Los resultados mostraron una estructura urbana policéntrica cuya movilidad por motivo ocupacional se sustenta en dos escalas temporales, la primera de escala barrial y con desplazamientos máximos de 15 minutos y la segunda de escala interurbana con desplazamientos máximos de 60 minutos en medios motorizados. En la Región Urbana Costera Puerto Vallarta-Bahía de Banderas, México el reparto modal mostró un predominio de los desplazamientos en medios motorizados en el nodo principal y sus localidades integradas; las localidades turísticas de mayor consolidación y las receptoras de inmigrantes con mayor expansión formal. Mientras que los desplazamientos a pie tienen mayor representación en localidades receptoras de inmigrantes con mayor urbanización informal, las de vocación turística de menor consolidación y las de transición rural-urbana más alejadas y con menor accesibilidad al trasporte motorizado, ya sea por la condición socioeconómica de sus residentes o por la cobertura del servicio de trasporte público. Así las dinámicas de proximidad se presentan en las localidades con menor accesibilidad socioeconómica y física a los medios motorizados y paradójicamente son estas las que presentan la mayor habitabilidad de la región.
\end{abstract}

Palabras clave: Movilidad cotidiana; proximidad urbana; habitabilidad; región urbana costera

Citación

Olivares, A. et al. (2021). Aproximación a la habitabilidad urbana desde la movilidad cotidiana y la proximidad. Región urbana costera Puerto Vallarta-Bahía de Banderas, México. México, ACE Architecture, City and Environment, 16(47), 10686. DOI: http://dx.doi.org/10.5821/ace.16.47.10686

\section{Approach to urban habitability from everyday mobility and urban proximity. Urban coastal region of Puerto Vallarta-Bahía de Banderas, Mexico}

Abstract

\begin{abstract}
The aim of this research was to identify the structure and habitability of the Touristic Urban Region Puerto Vallarta-Bahía de Banderas through everyday mobility and dynamics of proximity, the latter considered as an indicator of habitability. The data on everyday mobility come from the survey carried out in 2011 for the research "Urban Tourist Regions" (CONACYT CB-103363) and from the Intercensal Survey 2015, while the demographic and territorial data come from the 2005 Population and Housing Count of the General Population and Housing Census 2010 and of the vector information of the Geostatistical Framework version 5.0 of the INEGI. The results showed a polycentric urban structure whose everyday mobility is based on two-time scales: the first at neighborhood scale, with daily travels of up to 15 minutes; the second at interurban scale, with daily travels between 16 and 60 minutes using motorized transport. The modal distribution showed a predominance of journeys using motorized transport in the Main Node (Puerto Vallarta), the Integrated Urban Settlements, the Touristic Urban Settlements with further consolidation, and the Immigrant Receiving Urban Settlements with formal growth. Pedestrian travels have greater representation in Immigrant Receiving Urban Settlements (with mostly informal growth), Settlements with Tourist Vocation (with less consolidation) and more remote Rural-Urban Transition Settlements (with less access to motorized transport), either because the socioeconomic status of its residents or because the lesser service coverage of public transport. So, dynamics of proximity are presented as a resilient capability of communities with lower socioeconomic and physical access to motorized transportation; they also provide some components of habitability.
\end{abstract}

Keywords: Everiday mobility; proximity; habitability; coastal urban region

Dra. Arquitecta, Universidad de Guadalajara, UdeG (ORCiD: 0000-0002-7391-0684; Scopus Author ID: 43461850900), 2 Dra. en Geografía, Universidad Autónoma de Barcelona, UAB (ORCiD: 0000-0003-4821-9776; Scopus Author ID: 6505901341, WoS ResearcherID: M-6156-2015), ${ }^{3}$ Dr. en Filosofía, Universidad de Guadalajara, UdeG. Correo de contacto: ines.olivares@academicos.udg.mx

ACE, X (XX) CC BY-ND 3.0 ES | UPC Barcelona, España | Aproximación a la habitabilidad urbana desde la movilidad cotidiana y la proximidad. Región urbana costera Puerto Vallarta-Bahía de Banderas, México. DOI: http://dx.doi.org/10.5821/ace.16.47.10686 